\title{
INFLUENCE OF INJECTION PRESSURE ON EXHAUST EMISSIONS OF INSULATED DIESEL ENGINE FUELLED WITH BIOGAS AND BIODIESEL
}

\author{
B. Rama Krishna ${ }^{1}$, M.V.S. Murali Krishna ${ }^{2 *}$ and P. Usha Sri ${ }^{3}$ \\ ${ }^{1}$ Mechatronics Engineering Department, \\ Mahatma Gandhi Institute of Technology, Gandipet, Hyderabad, India \\ ${ }^{2}$ Mechanical Engineering Department, \\ Chaitanya Bharathi Institute of Technology, Gandipet, Hyderabad, India \\ ${ }^{3}$ Mechanical Engineering Department, College of Engineering, \\ Osmania University, Hyderabad, India \\ *Corresponding Author
}

\begin{abstract}
As the fossil fuels are depleting day by day due to heavy demand in various sectors like agriculture, transport etc., escalation of fuel prices in International Oil Market causing economic burden on developing countries like India and increase of environmental problems like Global warming and Green-house effect with IC engine with the use of fossil fuels, the search for alternative fuels has become pertinent and necessary. Gaseous fuels have many advantages than liquid fuels, as their calorific values of fuels are high, pollutants emitted by gaseous fuels are low and less dangerous when compared with liquid fuels. The drawbacks associated with use of vegetable oils in diesel engines such as high viscosity and low volatility can be reduced to some extent by converting them into biodiesel. However, they (biodiesel) cause combustion problems in diesel engine and hence call for low heat rejection (LHR) engine, which can burn low calorific value fuel, give high heat release rate and faster rate of combustion. They are many methods to induct gaseous fuels such as port injection, carburetion technique, injection of gaseous fuel at the near end of compression stroke etc,. Investigations were carried out with biogas gas as primary fuel inducted by port injection and cottonseed biodiesel was injected into the engine in conventional manner. Particulate matter (PM), oxides of nitrogen $\left(N O_{x}\right)$, carbon mono oxide $(C O)$ levels and un-burnt hydro carbons (UBHC) are the exhaust emissions from a diesel engine. They cause health hazards, once they are inhaled in. They also cause environmental effects like Green-house effect and Global Warming. Hence control of these emissions is an immediate effect and an urgent step. The pollutants of $\mathrm{PM}, \mathrm{NO} \mathrm{O}_{x} \mathrm{CO}$ and $\mathrm{UBHC}$ were determined at full load operation of the engine with varied injection pressure and compared with diesel operation on conventional engine. The maximum induction of biogas was $35 \%$ of total mass of biodiesel as full load operation. Particulate emissions
\end{abstract}


Influence of Injection Pressure on Exhaust Emissions of Insulated Diesel Engine Fueled with Biogas and Biodiesel

were determined by AVL Smoke meter, while other emissions were measured by Netel Chromatograph multi-gas analyzer at full load operation. These pollutants were drastically reduced with induction of biogas and further reduced with an increase of injection pressure.

Keywords: Diesel, biodiesel, CE, LHR engine, Exhaust emissions.

Cite this Article: B. Rama Krishna, M.V.S. Murali Krishna and P. Usha Sri, Influence of Injection Pressure on Exhaust Emissions of Insulated Diesel Engine Fueled with Biogas and Biodiesel, International Journal of Mechanical Engineering and Technology (IJMET), 12(7), 2021, pp. 23-32.

https://iaeme.com/Home/issue/IJMET?Volume=12\&Issue=7

\section{INTRODUCTION}

The civilization of a particular country has come to be measured on the basis of the number of automotive vehicles being used by the public of the country. The tremendous rate at which population explosion is taking place imposes expansion of the cities to larger areas and common man is forced, these days to travel long distances even for their routine works. This in turn is causing an increase in vehicle population at an alarm rate thus bringing in pressure in Government to spend huge foreign currency for importing crude petroleum to meet the fuel needs of the automotive vehicles. The large amount of pollutants emitting out from the exhaust of the automotive vehicles run on fossil fuels is also increasing as this is proportional to number of vehicles. In view of heavy consumption of diesel fuel involved in not only transport sector but also in agricultural sector and also fast depletion of fossil fuels, the search for alternate fuels has become pertinent apart from effective fuel utilization which has been the concern of the engine manufacturers, users and researchers involved in combustion \& alternate fuel research.

Rudolph diesel, the inventor of the engine that bears his name, experimented with fuels ranging from powdered coal to peanut oil [1] Several researchers conducted investigations on biodiesel with conventional engine (CE) and reported that the performance marginally improved, along with reduction of particulate emissions. [2-8]. However, they further reported that $\mathrm{NO}_{\mathrm{x}}$ emissions were marginally higher with biodiesel operation in comparison with neat diesel operation on CE.

The concept of LHR engine is to reduce heat loss to coolant by providing thermal insulation in the path of heat flow to the coolant. LHR engines are classified depending on degree of insulation such as low grade or LHR-1, medium grade or LHR-2 and high grade insulated engines or LHR-3 engine. Several methods adopted for achieving low grade LHR engines are using ceramic coatings on piston, liner and cylinder head, while medium grade LHR engines provide air gap in the piston and other components with low-thermal conductivity materials like superni, cast iron and mild steel etc and high grade LHR-3 engine is the combination of low grade and medium grade engines.

Experiments were conducted on low grade LHR engines with diesel and reported that diesel operation with LHR-1 engine improved performance and reduced particulate levels [9-11]. However, they increased nitrogen oxide levels $\left(\mathrm{NO}_{\mathrm{x}}\right)$ levels.

Investigations were carried out with low grade LHR engines with biodiesel and reported that biodiesel operation with LHR-1 engine improved performance and reduced particulate emissions.[12-14]. However, they increased $\mathrm{NO}_{\mathrm{x}}$ levels.

Biogas is produced by extracting chemical energy from organic materials in a sealed container called a digester. [15].The generation of biogas is the concept of anaerobic digestion, also called biological gasification. It is a naturally occurring, microbial process that converts 
organic matter to methane and carbon dioxide. The chemical reaction takes place in the presence of methanogenic bacteria with water an essential medium. The anaerobic digestion process, as the name states, is one that functions without molecular oxygen. Ideally, in a biogas plant there should be no oxygen within the digester. Oxygen removal from the digester is important for two main reasons. First, the presence of oxygen leads to the creation of water, not methane. Second, oxygen is a contaminant in biogas and also a potential safety hazard. Due to presence of oxygen, calorific value of biogas becomes low. Table.1 shows composition of biogas

Table 1 Composition of biogas

\begin{tabular}{|l|l|}
\hline \multicolumn{1}{|c|}{ Components } & \multicolumn{1}{c|}{ Amount (\%) } \\
\hline Methane ( CH4 ) & $50-70$ \\
\hline Carbon Dioxide (CO2) & $30-40$ \\
\hline Hydrogen (H2) & $5-10$ \\
\hline Nitrogen $(\mathrm{N} 2)$ & $1-2$ \\
\hline Water Vapour $\left(\mathrm{H}_{2} \mathrm{O}\right)$ & 0.3 \\
\hline Hydrogen Sulphide $\left(\mathrm{H}_{2} \mathrm{~S}\right)$ & Hydrogen Sulphide $\left(\mathrm{H}_{2} \mathrm{~S}\right)$ \\
\hline
\end{tabular}

$\mathrm{CO}_{2}$ is high corrosive when wet and it has no combustion value so its removal is must to improve the biogas quality. The processes to remove $\mathrm{CO}_{2}$ are as follows

a) Caustic solution, NAOH- $40 \% \mathrm{NAOH}+\mathrm{CO}_{2}=\mathrm{NAHCO}_{3}$

b) Refined process, $\mathrm{K}_{2} \mathrm{CO}_{3}-30 \% \mathrm{~K}_{2} \mathrm{CO}_{3}+\mathrm{CO}_{2}=2 \mathrm{KCO}_{3}$

Investigations were carried out with biogas in conventional engine. The dual fuel mode exhibited lower peak values of heat release rate and also they reported the application of exhaust gas recirculation (EGR) to dual-fuel mode additionally decreased the in-cylinder pressure and increased the ignition delay. [16]. Dual fuel mode displayed lower emissions of $\mathrm{NO}_{\mathrm{x}}$ and smoke opacity while $\mathrm{HC}$ and $\mathrm{CO}$ concentrations were considerably higher as compared to other fuels. In dual fuel mode peak pressure and heat release rate were slightly higher compared to diesel and biodiesel mode of operation for all engine loads. [17]. Investigations were carried out with biogas, diesel-methane, and neat diesel operation in conventional engine [18]. They observed higher brake thermal efficiencies compared to diesel mode at high loads. Though volumetric efficiency was almost identical in diesel and diesel-CH4 dual modes, exhaust gas temperatures were higher in diesel-biogas mode, followed by diesel-methane and diesel modes.[18] . $\mathrm{NO}_{\mathrm{x}}$ is a strong function of local temperatures. They reported that in compression ignition engine at constant speed of $1500 \mathrm{r} / \mathrm{min}$ at full load both $\mathrm{NO}_{\mathrm{x}}$ and soot missions were dropped, energy content rates in gas-fuel mixture compared to only diesel fuel[19].

However, little reports were available with the use of biogas and biodiesel. Hence authors have made work in this direction. It is attempted to determine the pollution levels of conventional engine with biogas and cottonseed biodiesel with varied injection pressure and compared the data with diesel operation on CE. 


\section{MATERIALS AND METHODS}

\subsection{Experimental Set-up}

Table. 1 gives the details of the engine

Table 1 Details of the Engine

\begin{tabular}{|l|l|}
\hline \multicolumn{1}{|c|}{ Description } & \multicolumn{1}{c|}{ Specification } \\
\hline Make & Mahindra \& Mahindra \\
\hline Number of cylinders & 01 \\
\hline Number of Strokes & 04 \\
\hline Ratio of bore to stroke & $93 \mathrm{~mm} / 92 \mathrm{~mm}$ \\
\hline Power & $6.6 \mathrm{~kW}(9 \mathrm{HP})$ at the rated speed of 3000rpm \\
\hline Compression Ratio & $18: 1$ \\
\hline Type of cooling Arrangement & Water cooling \\
\hline Recommended Injection Pressure & $190 \mathrm{bar}$ \\
\hline Recommended Injection Timing & 27 degrees before top dead centre \\
\hline Maximum Torque & $30 \mathrm{Nm}$ at $1800 \mathrm{rpm}$. \\
\hline
\end{tabular}

Fig.1 shows that the test engine (1) and the details of the CRDi engine are given in Table.1 It was located at Applied Thermo Dynamics Laboratory of MED, CBIT, Hyderabad. The engine was connected to power measuring device (2). The engine had computerized test bed. There was facility of loading the engine by means of variable rheostat. (3). Outlet jacket water temperature was indicated with temperature sensor (4). The flow of the coolant was measured with flow meter (5). The temperature of the exhaust gas was indicated with exhaust gas temperature sensor (6). The particulate levels were determined with AVL Smoke meter (7) at full load operation. The pollutants of $\mathrm{CO}$ and UBHC were determined by Netel Chromatograph multi gas analyzer (8) at full load operation. The range and accuracy of the analyzers in multi gas analyzer are shown in Tabl.2. EGR (9) system was employed in the system to reduce $\mathrm{NO}_{\mathrm{x}}$ emissions. Air flow was measured with air flow sensor (10). Biodiesel tank (11), burette (12) and three way valve (13) were used to induct biodiesel into the engine in conventional injection system. Bypass system was provided for EGR system. Air box arrangement (14) along with water manometer was employed to measure air flow rate from atmosphere. Directional valves (15) were provided for bypass system. Biogas clean from $\mathrm{CO} 2$ was stored in a gas cylinder (16). Pressure regulator (17) was incorporated in the system. The pressure of the gas was noted in gas pressure sensor (18). The mass flow rate of the gas was noted by means of a rotometer (19). The flame arrestor (20) was employed in the gas circuit to ensure safety. Cam position senor was used to measure injection timing. Crank position sensor was used to determine the speed of the engine. Fuel temperature was determined with fuel temperature sensor. Gas was injected through gas injector.

Table 2 Range and accuracy of Analyzers

\begin{tabular}{|c|l|l|l|l|}
\hline S.No & \multicolumn{1}{|c|}{$\begin{array}{c}\text { Name of the } \\
\text { Analyzer }\end{array}$} & \multicolumn{1}{|c|}{ Principle adopted } & \multicolumn{1}{|c|}{ Range } & Accuracy \\
\hline 1 & AVL Smoke Analyzer & Opacity & $\begin{array}{l}0-100 \text { HSU } \\
\text { (Hartridge Smoke Unit) }\end{array}$ & $\pm 1 \mathrm{HSU}$ \\
\hline 2 & $\begin{array}{l}\text { Netel Chromatograph } \\
\text { CO analyzer }\end{array}$ & $\begin{array}{l}\text { Infrared absorption } \\
\text { spectrograph }\end{array}$ & $0-10 \%$ & $\pm 0.1 \%$ \\
\hline 3 & $\begin{array}{l}\text { Netel Chromatograph } \\
\text { UBHC analyzer }\end{array}$ & NDIR & $0-1000 \mathrm{ppm}$ & $\pm 5 \mathrm{ppm}$ \\
\hline 4 & $\begin{array}{l}\text { Netel Chromatograph } \\
\text { NO }\end{array}$ analyzer & Chemiluminiscence & $0-5000 \mathrm{pm}$ & $\pm 5 \mathrm{ppm}$ \\
\hline
\end{tabular}




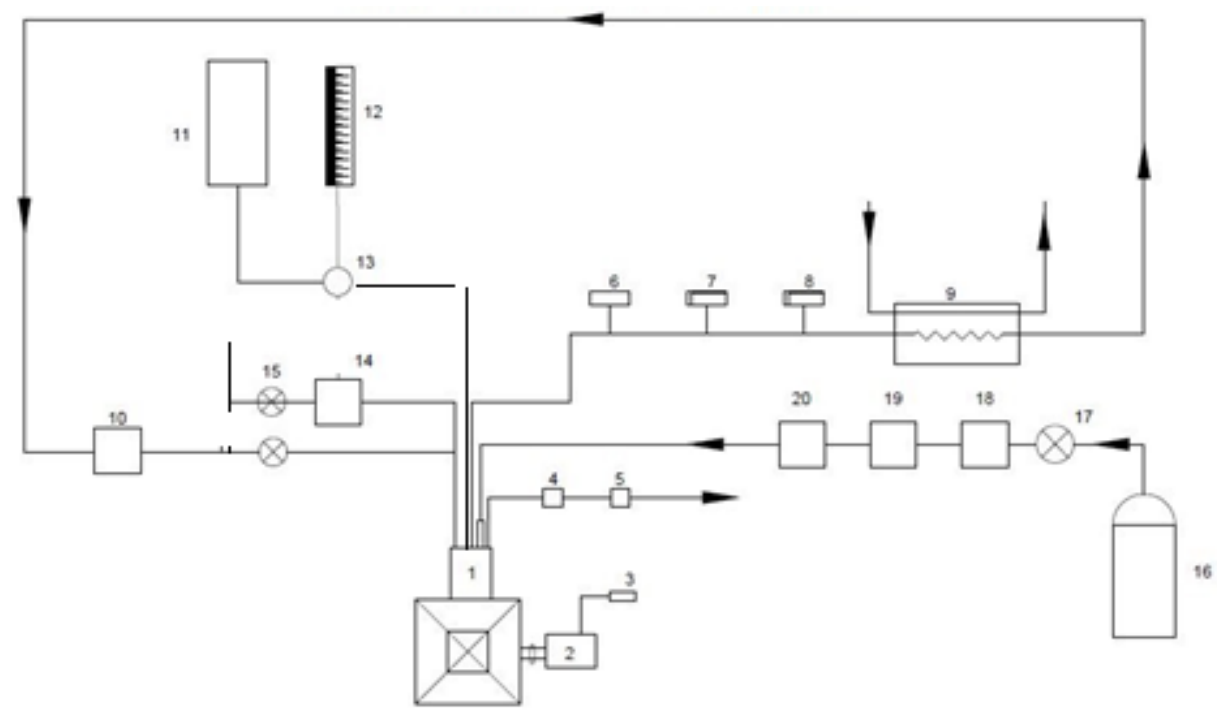

Figure 1 Schematic diagram of experimental set up

1.Engine, 2. Electical Dynamometer, 3. Load Box, 4. Outlet jacket water temperature indicator, 5. Outlet-jacket water flow meter Orifice meter, 6. Exhaust gas temperature indicator, 7 AVL Smoke meter, 8. Netel Chromatograph multi-gas analyzer 9. Heat exchanger, 10. Air flow sensor, 11. Biodiesel tank, 12. Burette, 13. Three-way valve, 14. Air box with manometer arrangement, 15. Directional valve, 16. Gas cylinder, 17. Pressure regulator,18. Gas pressure sensor, 19. Flame arrestor and 20Rotometer

The engine was provided with gravity lubrication system. Biogas was inducted through port injection at the near end of compression stroke of the engine. There was facility to increase injection pressure by means of sensor.

The test fuels of the investigations were i) neat diesel and ii) biogas and biodiesel. The configurations or the versions of the engine were normal or base engine and insulated engine. Pollutants of $\mathrm{CO}$ and UBHC were determined at full load of the engine, at different injection pressures with test fuels.

\section{RESULTS AND DISCUSSION}

Fig. 2 shows the variation of brake thermal efficiency (BTE) with brake power (BP) of LHR engine with various percentages of biogas induction along with biodiesel operation. BTE increased with an increase of BP up to $80 \%$ of the full load and beyond that load, it decreased with different percentages of induction of biogas. This is due to increase of fuel conversion efficiency and mechanical efficiency up to $80 \%$ of the full load causing increase of BTE. However, beyond $80 \%$ of the full load, decrease of fuel conversion efficiency and oxygen-fuel ratio made reduction of BTE. At all loads, BTE increased with increase of induction of biogas up to $45 \%$. This is due to improved oxidation reaction of $\mathrm{CH} 4$ in biogas and $\mathrm{O} 2$ in the hot combustion chamber provided by LHR engine. However, beyond 45\% induction of biogas, BTE decreased at all load when compared with neat diesel operation on CE. This is due to reduction of ignition delay with biogas causing to produce peak pressure at an early stage. Hence the optimum induction of biogas was limited up to $45 \%$ of total consumption of biodiesel by mass basis along with diesel operation. 


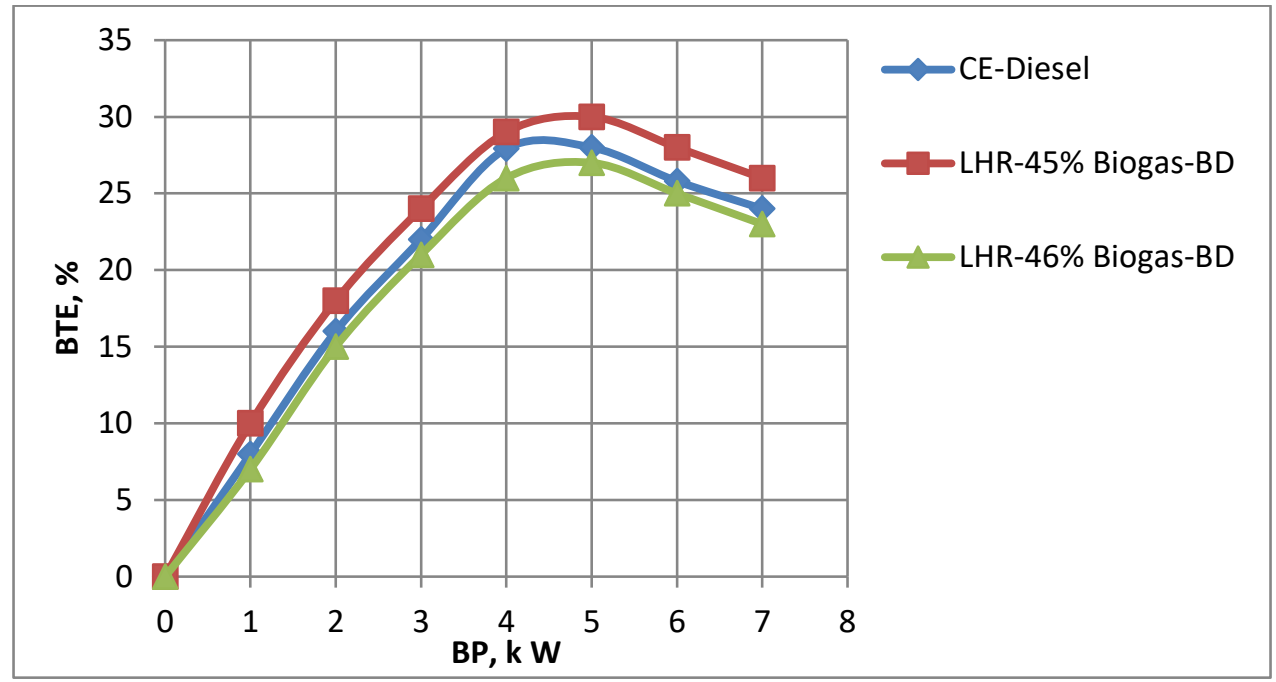

Figure 2. Variation of BTE with BP in LHR engine with biogas and biodiesel

Fig. 3 presents the bar chart showing the variation of particulate emissions in Hartridge Smoke Unit (HSU) at full load with LHR engine at maximum induction of biogas with varied injection pressure.

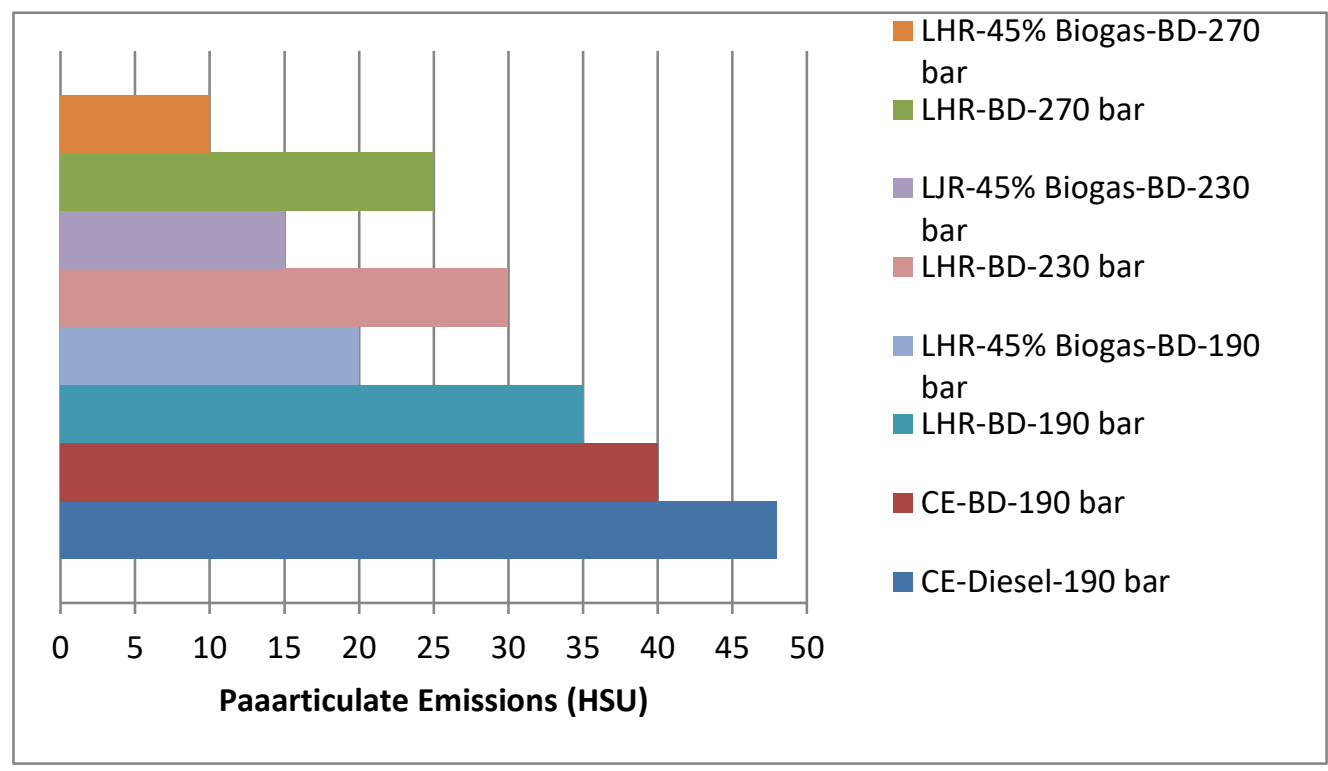

Figure 3 Variation of particulate emissions at full load with injection pressure.

Particulate emissions at full load decreased with increased injection pressure with different operating conditions of the engine. This is due to improved spray characteristics and atomization of the fuel spray which is penetrating through oxygen zone. Particulate emissions at full load decreased with increase of induction of biogas at different injection pressures. Improved oxidation reaction of $\mathrm{CH} 4$ present in the biogas and oxygen present in the biodiesel with faster rate of combustion had caused reduction of particulate emissions at full load.

Fig.4 presents the bar chart showing the variation of $\mathrm{NO}_{\mathrm{x}}$ levels at full load with LHR engine at maximum induction of biogas with varied injection pressure. $\mathrm{NO}_{\mathrm{x}}$ levels increased with increased injection pressure with test fuels. Increase of combustion temperatures increased $\mathrm{NO}_{\mathrm{x}}$ levels with test fuels. $\mathrm{NO}_{\mathrm{x}}$ levels decreased with induction of biogas. This is due to presence of oxygen in biodiesel improved combustion, due to enrichment of oxygen with oxidation reaction of $\mathrm{CH} 4$ present in biogas with oxygen present with biodiesel. 


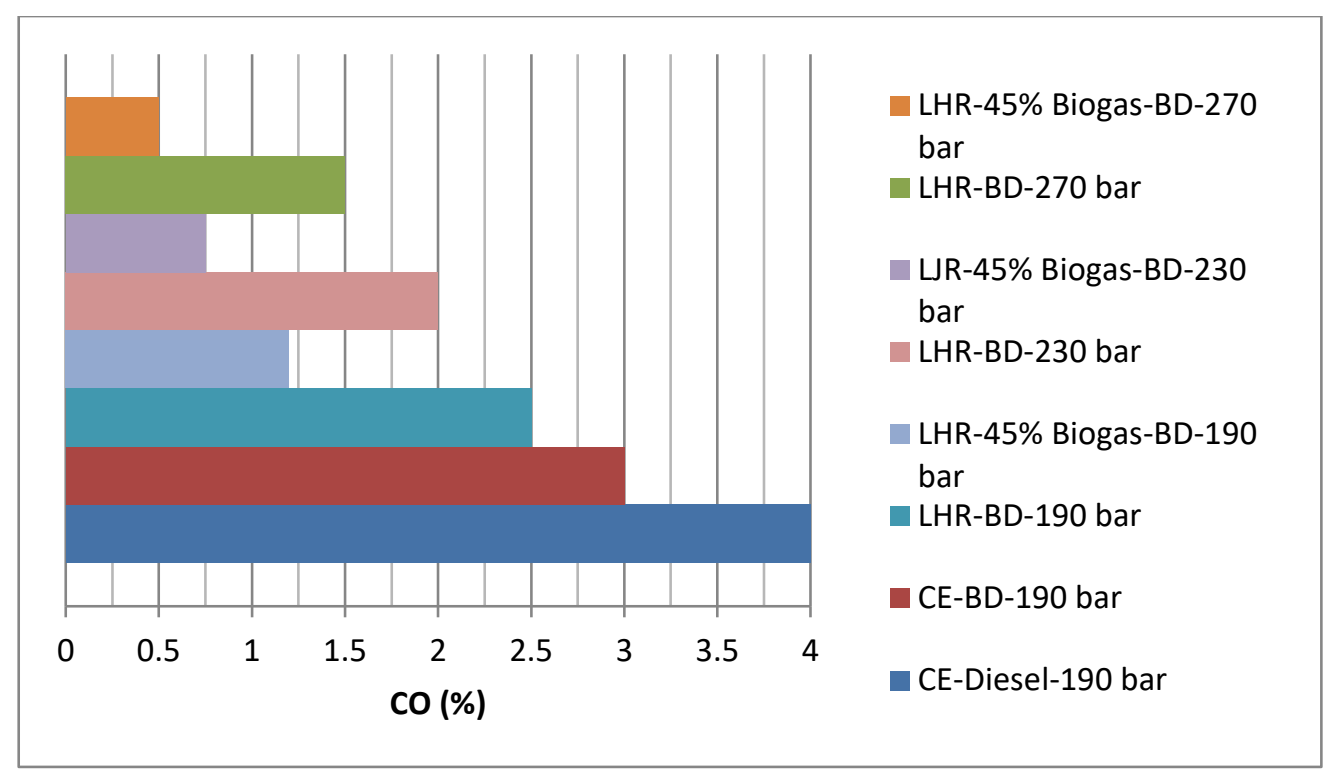

Figure 4 Variation of Nitrogen Oxide emissions at full load with injection pressure.

Fig.5. presents the bar chart showing the variation of carbon monoxide (CO) emissions at full load with $\mathrm{CE}$ at maximum induction of biogas with varied injection pressure. $\mathrm{CO}$ emissions decreased with an increase of injection pressure with test fuels at different operating conditions of the engine. This is due to improved spray characteristics of the fuel. When the injection pressure increased, the depth of penetration of the fuel increased in oxygen zone leading to improve oxidation reaction of the fuel with oxygen with not only in the environment but also available with biodiesel causing improved combustion and reduced $\mathrm{CO}$ emissions. $\mathrm{CO}$ emissions decreased with biodiesel operation. This is due to improved combustion with presence of oxygen in biodiesel molecular composition. This is also due to improved cetane number of biodiesel causing improved combustion leading to reduce $\mathrm{CO}$ emissions. $\mathrm{CO}$ emissions reduced with biogas induction. This is due to improved oxidation reaction of $\mathrm{CH} 4$ with oxygen available with biodiesel. Improved cetane (a measure of ignition quality of the fuel in diesel engine) number of biodiesel also improved combustion and thus reduced $\mathrm{CO}$ emissions. Combustion improved with LHR engine due to improved heat release rate had caused reduction of $\mathrm{CO}$ emissions.

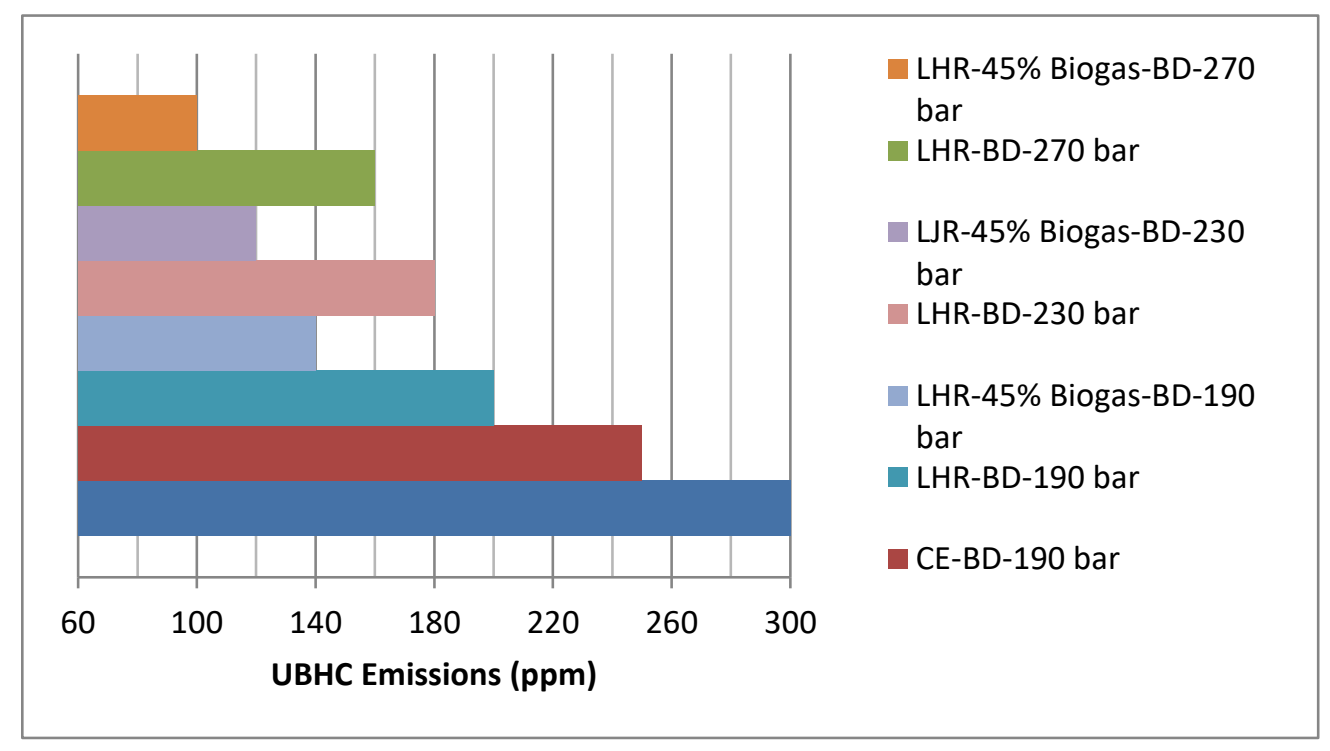

Figure 6 Variation of $\mathrm{CO}$ emissions at full load with injection pressure. 
Fig.7 presents the bar chart showing the variation of un-burnt hydro carbon (UBHC) emissions at full load with $\mathrm{CE}$ at maximum induction of biogas with varied injection pressure. The UBHC emissions at full load followed similar trends with $\mathrm{CO}$ emissions. $\mathrm{CO}$ is formed due to incomplete combustion of the fuel, while UBHC emissions are formed due to accumulation of the fuel in the crevice volume. UBHC emissions decreased with increased injection pressure at different operating conditions of the engine with test fuels. This is due to improved oxidation reaction of the fuel with increased fuel spray characteristic of the fuel along with atomization characteristics of the fuel. When the fuel injection pressure increased, number of fuel particles will increase along with reduction of mass, having good exposure of the fuel with oxygen particles due to improved surface to volume ratio. UBHC emission decreased with biodiesel operation. Presence of oxygen in its molecular composition and high cetane number of biodiesel improved combustion and hence reduced the un-burnt fuel in the crevice volume, thus reducing UBHC emissions. UBHC emissions at full load decreased with induction of biogas. LHR engine reduced UBHC emissions drastically with improved combustion due to improved heat release rate.

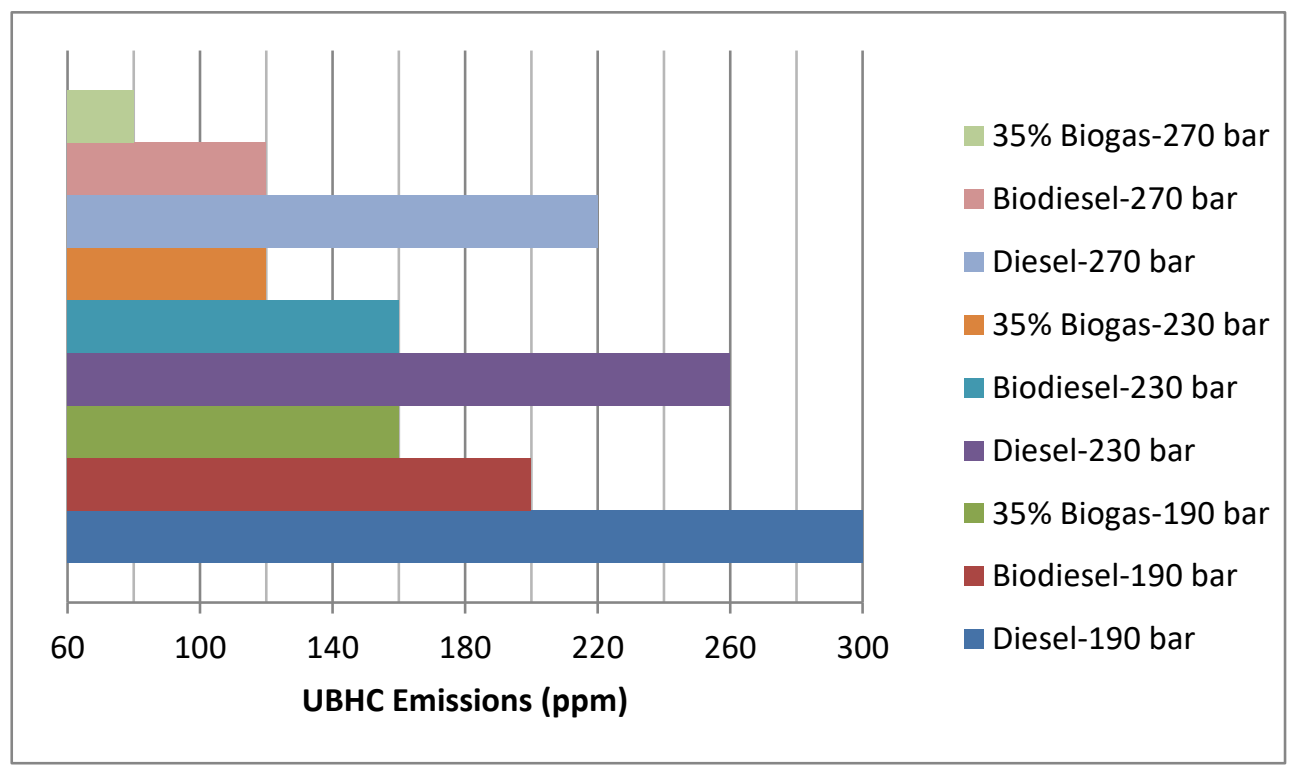

Figure 7 Variation of UBHC emissions at full load with injection pressure.

High cetane number and presence of oxygen in the molecular structure of biodiesel caused improved oxidation reaction of $\mathrm{CH} 4$ present in biogas and thus reduced accumulation of the fuel in the crevice volume leading to reduce UBHC emissions at full load with induction of biogas.

\section{CONCLUSIONS}

The maximum induction of biogas in LHR engine was $45 \%$ of total mass of diesel at full load operation. Particulate emissions, nitrogen oxide levels, carbon monoxide levels and un-burnt hydro carbons drastically decreased drastically with dual fuel operation in comparison with neat diesel operation on conventional engine. LHR engine drastically reduced pollutants in comparison with CE. Increased injection pressure from 190 bar to 270 bar marginally decreased pollutants with test fuels. 


\section{ACKNOWLEDGMENTS}

Authors thank authorities of Chaitanya Bharathi Institute of Technology, Hyderabad for providing facilities for carrying out research work. Financial assistance provided by All India Council for Technical Education (AICTE), New Delhi, is greatly acknowledged.

\section{REFERENCES}

[1] Cummins, C. Lyle, Jr. (1993). Diesel's Engine, Volume 1: From Conception To 1918. Wilsonville, OR, USA: Carnot Press.

[2] Agarwal, A.K. (2006). Bio-fuels (alcohols and biodiesel) applications as fuels for internal combustion engines, International Journal Energy Combustion Science, 33,233-271. Available from: https://doi.org/10.1016/j.pecs.2006.08.003

[3] Rasim, B. (2011). Performance and emission study of waste anchovy fish biodiesel in a diesel engine, Fuel Processing Technology, 92, 1187-1194. Available from: https://doi.org/10.1016/j.fuproc.2011.01.012

[4] Jaichandar, S. and Annamalai, K. (2011). The status of biodiesel as an alternative fuel for diesel engine- An Overview, Journal of Sustainable Energy \& Environment, 2, 71-75. Available from: https://www.thaiscience.info/journals/Article/JOSE/10889665.pdf

[5] Ridvan Arslan. (2011). Emission characteristics of a diesel engine using waste cooking oil as a bio-diesel fuel, African Journal of Bio-Technology, 10(9),3790-3794. Available from: https://www.ajol.info/index.php/ajb/article/view/93532

[6] Xue, J., Grift, T.E., Hansen, A.C. (2011). Effect of biodiesel on engine performances and emissions, Renewable and Sustainable Energy Reviews,15, 1098-1116. Available from: https://doi.org/10.1016/j.rser.2010.11.016

[7] McCarthy, P., Rasul, M.G., Moazzem, S. (2011). Analysis and comparison of performance and emissions of an internal combustion engine fuelled with petroleum diesel and different biodiesels, Fuel, 90, 2147-2157. Available from: https://doi.org/10.1016/j.fuel.2011.02.010

[8] Durga Prasada Rao, N., Murali Krishna, M.V.S., Anjeneya Prasad, B., and Murthy, P.V.K. (2014). Effect of injector opening pressure and injection timing on exhaust emissions and combustion characteristics of rice bran oil in crude form and biodiesel form in direct injection diesel engine. IOSR Journal of Engineering 4(2), 9-19. Available from: http://iosrjen.org/Papers/vol4_issue2\%20(part-7)/B04270919.pdf

[9] Parlak, A., Yasar, H., ldogan O. (2005). The effect of thermal barrier coating on a turbocharged Diesel engine performance and exergy potential of the exhaust gas. Energy Conversion and Management,46(3), 489-499. Available from: https://doi.org/10.1016/j.enconman.2004.03.006

[10] Ekrem, B., Tahsin, E., Muhammet, C. (2006). Effects of thermal barrier coating on gas emissions and performance of a LHR engine with different injection timings and valve adjustments, Journal of Energy Conversion and Management, 47, 1298-1310. Available from: https://doi.org/10.1016/j.enconman.2005.06.021

[11] Ciniviz, M., Hasimoglu, C., Sahin, F., Salman, M. S. (2008). Impact of thermal barrier coating application on the performance and emissions of a turbocharged diesel engine. Proceedings of The Institution of Mechanical Engineers Part D-Journal of Automobile Eng,222 (D12), 24472455. Available from: https://doi.org/10.1243/09544070JAUTO851 
Influence of Injection Pressure on Exhaust Emissions of Insulated Diesel Engine Fueled with Biogas and Biodiesel

[12] Rajendra Prasath, B., P. Tamilporai,P., Mohd. Shabir, F. (2010). Analysis of combustion, performance and emission characteristics of low heat rejection engine using biodiesel, International Journal of Thermal Sci, 49, 2483-2490.

[13] Mohamed Musthafa, M., Sivapirakasam, S.P. and Udaya Kumar.M. (2011). Comparative studies on fly ash coated low heat rejection diesel engine on performance and emission characteristics fueled by rice bran and pongamia methyl ester and their blend with diesel. Energy, 36(5).2343-2351. Available from: https://doi.org/10.1016/j.energy.2010.12.047

[14] Ratna Reddy, T., Murali Krishna, M.V.S., Kesava Reddy, Ch. and Murthy, P.V.K. (2012). Performance evaluation of mohr oil based biodiesel in low grade low heat rejection diesel engine, International Journal of Innovative Research in Science, Engineering and Technology, 1(1), 80-94. Available from: http://citeseerx.ist.psu.edu/viewdoc/download?doi=10.1.1.1062.7054\&rep=rep1\&type $=p d f$

[15] Ray, N.H.S., Mohanty, M.K. and Mohanty, R.C. (2013), Biogas as an alternative fuel in diesel engines- A literature review, IOSR Journal of Mechanical and Civil Engineering, Volume 9(1), $23-28$

[16] Abdelaal, M.M., Hegab, A.H. (2012). Combustion and emission characteristics of a natural gasfueled diesel engine with EGR, Energy Conversion and Management 64 (1), 301-312. Available from: https://doi.org/10.1016/j.enconman.2012.05.021

[17] Ramesha, D.K., Adhiviraj Singh Bangari, Chirag P. Rathod, Samartha Chaitanya R.(2015). Experimental investigation of biogas-biodiesel dual fuel combustion in a diesel engine, Journal of Middle European Construction and Design of Cars. Available from: https://doi.org/10.1515/mecdc-2015-0003.

[18] Feroskhan.M. and Saleel Ismail (2016), Investigation of the effects of biogas composition on the performance of a biogas-diesel dual fuel CI engine, Informa UK Limited, trading as Taylor \& Francis Group Biofuels, Vol 7,593-601, Available from: https://doi.org/10.1080/17597269.2016.1168025.

[19] Yasin Karagoz, Tarkan Sandalc, Umit O Koylu, Ahmet Selim Dalk1licx and Somchai Wongwise (2016). Effect of the use of natural gas-diesel fuel mixture on performance, emissions, and combustion characteristics of a compression ignition engine -Advances in Mechanical Engineering, Vol. 8(4) 1-13, 2016, Available from: https://doi.org/10.1177/1687814016643228 